\title{
Education for Employment: Is the Null Hypothesis Proven Too Frequently?
}

\author{
Mary Ann Hollingsworth (PhD) \\ University of West Alabama, United States
}

Doi: 10.19044/esj.2017.c1p9 URL:http://dx.doi.org/10.19044/esj.2017.c1p9

\begin{abstract}
Employment prospects vary for college graduates, with a few courses of study leading to an overabundance of opportunity. For the majority of students, there is significant mismatch between training preparation and actual job demand in either type of job, location of job, or skills required in job. This qualitative study examined integration of desired employment activities and aptitudes into 30 sections of different graduate courses in counseling over four school years to ascertain student perception of enhancement of job preparation. Activites focused on four areas that research indicated to offer benefit for student employment preparation: engagement in work-simulated skills practice; engagement in course group activiteis; participation in service learning volunteerism; and student pro-activity. Many students were already working in the general field of study such as school teachers pursuing a degree in school counseling. Student feedback indicated perceived benefit and efficacy toward preparation for desired post-degree job. Further study is indicated in this potential integration with expansion of study into multiple fields of study and into both undergraduate and graduate programs.
\end{abstract}

Keywords: Job Preparation, Job Mismatch, Employment preparation

\section{Introduction}

A student most often goes to college with the hypothesis that „This degree will get me this type of job." Employment prospects vary for college graduates. For some, such as health care and insurance/risk-management, there may be more opportunities available than students seeking that work. In other areas, such as some liberal arts majors, students may not find a desired job upon completion of the undergraduate degree. In graduate school, students may pursue a degree as something to do because they do not find employment or per promise of an adanced salary or higher position with their current employer - thus using the degree for some improvement in the current job,but still not seeing the degree result in a new job or better job. For all of these 
students, the null hypothesis seems to be proved - that ,this degree did not get me this job." Rather, the degree was a mismatch for job type, or perhaps a mismatch for jobs in general. There are various reasons for results of the null hypothesis and also various treatments that can promote results of the research hypothesis regarding employment outcome with a college degree.

Coates and Edwards (2010) examined trends in college graduate perceptions of the relevance of courses taken in their degree program to postdegree employment and continued learning pathways. Their study specifically addressed the state of perceptions five years out from graduation. One of the strongest perceptions was that positive employment outcme was directly related to student investment of cost, time, and effort into completion of the degree. Most respondents to this study indicated perceived positive relevance of degree to bachelor degree field of study. However, the ratio of perceived relevance was considerably lower for efficacy of degree preparation for work. Coates and Edwards also noted that work readiness at the point of graduation does not well equate to desirable acculturaltion into their preferred career or profession. This acculturation could be enhanced through ,treatments“ while students are in their programs of study.

Wertel (2015) indicated that employment outcomes are generally impacted by ,regional differences, differences in the job market, and individual characteristics of students." (p. 33) The regional differences and differences in the job market may be outside the influence level of institutions, faculty, and students - but research indicates there are factors that can be employment by these to enhance employment outcomes for students so that ,this type of degree does result in this type of job.“

Nunley, Pugh, Romero, and Seals (2017) noted that a track record of underemployment for college graduates prompted 30 percent lower callback rates with employment than job applicants who were adequately employed at the time of application or who were unemployed (p. 642). Nunley, et al. also shared that employers tended to view underemployment with an applicant as syptomatic for possible lower productivity if hired. This study revealed that internship experience with degree programs significantly helped to offset a negative impact from underemployment.

The employment state for college graduates is a concern internationally. Lim, Rich, ane Harris (2008) noted that this concern was especially crucial with developing countries that depended greatly on feeding their ecomony through continual provision of an educated workforce. Lim, et al. examined factors that contributed the employment potential of college graduates. One of the crucial contributing factors was job mismatch.

Monetary compensation has often been touted as a value that improves with attainment of a college education. Roksa and Levey (2010) also examined other markers of efficacy with post-college employment. They 
specifically examined the relevance of work in a student's major field of study influenced work satisfaction and retention. Roksa and Levey noted that many college majors have not readily identifiable labor market match, such as majoring in liberal arts and general sciences. They stressed the value of accurate relationship between education offered and labor market demand.

\section{Literature review}

\section{Theory}

Lim, et al. (2008) discussed both job mismatch theory and job search theory as frameworks for unemployment. Job mismach theory posed that skills that did not fit employment needs would cause unemployoment. Job search theory poses that unemployment would be related to personal job seeker preferences and timing of job acquisition.

Lee (2015) examined the specificity of training to job requirements with influence on in-job behaviors as opposed to just general training to general job type. Lee noted that mismatch of training to job could result in diminished outcomes with desired behaviors and performance in the work plae - whether the mismatch was undertraining or overtraining. A key area of employee impact was in the psychological arena where an undertrained person could perceive injustice in being supported for optimal performance or for promotion. An example would be a classroom teacher who had no clue about classroom management of student behaviors. Overtrained persons may experience frustration or boredom at perceived limitations of their job or a sense of deserving something better. An example would be a student with a graduate degree in social work who could only find a bachelor's degree level position.

St. Clair, et al. (2017) explored the adaptation needed for doctoral students in career preparation for the non-traditional pathways from their programs that would be outside of academia. As institutions reinforced a traditional choice toward academia, students found that they had to independently frame preparation for a non-traditional choice versus relying on their program resources for adequate support. St. Clair, et al. Xx types of student prepartion that enhanced the efficacy of their non-traditional job search. Students could derive benefit from explicit resources or training. An example would be a doctoral student in counselor education who went through Play Therapy certification while in a degree program. Benefit was derived from alignment with a mentoring resource within the desired job arena. Finally, students indicated benefit from engagement in general career preparation entities such as credit or non-credit career prepartation courses and job fairs or networks. 


\section{Demand with Limited Supply}

In some areas of study, there seems to be consistent opportunity for employment for college graduates. These areas of study seemed to be specific vocation preparation, such as education, medicine, and law. Where a degree did not directly correlate to job type, the supply of students often exceded the demand for hire in jobs.

Gorski (2015) indicated that insurance and risk management companies offer excellent pay and positions, but college programs are not graduating enough students with degree preparation to meet this demand. Professors from various programs across the United States were said to note there were too many opporutnities for their students.

Another example was mentioned in the Buffalo News, November, 2015 ("ECC," 2015). That area has experience a shortage of nurses for many years. Lack of much opportunity to attain nursing education was cited as one of the major factors. A local community college addressed this issue in a winwin for both the college and area health care providers. The college consolidated its nursing program geographically near a major local medical campus.

\section{Supply with Limited Demand}

Lim, et al. (2008) found that the supply of students with non-vocational degrees such as humanities or liberal arts exceeded the demand of employment opportunities in available jobs. This can lead the recent graduate from a bachelor's program to choose to continue into graduate study for „something to do." Lim, et al. also noted that rather than providing assistance to match student to available jobs, institutions might be more receptive to facilitating retraining to improve student capacity for job acquisition. Examples of this facilitation could be increased leniency in acceptance of previous course work toward a new degree or development of specialization or certification programs that had more specific career focus.

Roksa and Levey (2010) provided occupational specificity from the National Center for Educational Statustics for several common college majors, with specificity relating to percentages of employment of student graduates in that field. The fields which saw the highest percentage of employed graduates were Education and Health. The fields which saw the lowest percentages of employed graduates were humanities; biological, math, and physical sciences; social sciences; and communication/journalism. Roksa and Levey noted that students who proceeded to graduate school were most often those who were also in the fields of study with the lower occuaptional speficicity. They noted that ,graduate degrees seemed to reinformce the patterns that were observed for undergraduate majors." (p. 403).

\section{Enhancement of Student Preparation}


Various studies have supported the efficacy of integration of hands-on experience in classes that mirrors future work experience. Examples are internships in the degree program, engagement in work-simulated skills practice or group activities in a course, service-learning projects in a course, volunteer work with discipline-related organizations, and use of action research in a course. Student preparation for employment was also enhanced through student personal pro-activity with job readiness, such as early planning and willingness to relocate.

Internships. Degree programs in primary health care, mental-health care, and education have integrated student internships for a number of years. Some degree

Nunley, et al. (2017) indicated that internship experience had significant impact on job acquisition and retention of discipline-related employment. In their study, the authors found that those job applicants who had no internship experience were called back for additional applicant processing at a 31 percent lower rate than those applicants who did have internship experience. In addition to provision of student preparation enrichment, internships also offered employers additional workforce from interns.

\section{Engagement in work-simulated skills practice}

Two modalities that have provided work-simulated skills practice are Problem-based learning and Project-Based Learning. Problem-based learning has been included as a motivation for student learning and also for improvided student degree prepartion alignment with chosen career path. Siew and Mapeala (2017) described the positive effects of Problem-based learning. to be increased student perception of task and learning value, increased student intrinsic goal-orientation, improvement in student self-efficacy beliefs, and improvement in student self-motivation. These positive effects are all supportive of accurate degree and job match for college graduates. Examples in higher education include periodic time in P12 classrooms for students in teacher preparation programs, lab components in courses from biology to counseling, and cores of Problem-based learning in some phases of veterinary education.

Kumari and Nandal (2016) examined the efficacy of Project-based learning in professional education through a Master of Business Administration (MBA) program. They examined the effectiveness of Projectbased learning and found consensus among participants that they received enhancement with analytical, interpersonal, leadership, technical, and collaborative skills. A key insight shared by the authors was the need for students to „inculcate their abilities and skills inrealistick working environments so that skills could be generated instead of mere theoretical 
knowledge.“ (p. 212). Kumari and Nandal noted accompanying benefit to employers through receipt of more competent new hires and this would in turn reduce training time and costs.

\section{Engagement in course group activities}

A natural component of PBL is often group work among students. Siew and Mapeala (2017) found that student groups which used a common set of procedures for thinking also experienced improvements in „critical thinking, interpersonal skills, problem-solving, and learning.“ (p. 380.) These skills translate well to the work place with group work serving to enhance such desirable skills.

Most work environments accomplish productivity through the efforts of groups. Konyu-Fogel, DuBois and Wallingford, (2013) indicated that student work in groups enhanced capacity of students with independent thinking, problem-solving skills, and other key skills desired by employers to promote effective work in teams on the job. Research seems to consistently emphasize the value that employers place on group skills and the ability to translate the theory of the academic classroom to practice in the work setting (Van der Putten and Vichit-Vadakan, 2010, Hamer and O'Keefe 2013, and Lou, 2004).

\section{Service-Learning and Volunteerism}

Integration of either/and Service-Learning and Volunteerism have been shown to better prepare students for post-graduate employment than does more traditioinal pedagogies of lecture or paper-writing. Both ServiceLearning and Volunteerism enrich student preparation as they learn by doing. Clayton (2009) indicated that Service-Learning adds the layer of insight gained from student reflection in three key areas: 1) Reflection on self as change agent with the focus issue; 2) Reflection on the relevance of the experience to what student is learning in the course, and 3) analysis of etiology of problem issues and how this will impact on student's future career work.

\section{Student pro-activity}

Wertel (2015) shared information on college graduate employment per The Outcome Survey of 2014. This showed that nine percent of students surveyd reported unemployment due to inability to find employment in the desired location for residence. Wertel also noted the value to students in starting a job search early, such as at least six months prior to graduation. Institutions of higher education can be proactive in provision of services to support students in early job search and development of desired employment skills such as work ethic, communication skills, and problem-solving capacity. 
Lim et al. (2008) indicated that English language proficience influence factors of employment such as acquisition of employment as well as job constiuents such as hours of work and wages. These authors also examined types of degrees and employment outcome. Degrees categorized as vocational degrees (eg. meedicine and law, p. 324) supported better employment outcome than did degrees with less clear vocational alignment such as the studies of humanities or liberal arts. Lim, et al. also noted the value of proficiency in work skills such as capacity for effective communication.

\section{Work-related terminal degrees}

An emerging practice is the work-related doctorate. Costley and Lester ( 2012) discussed the efficacy of this practice for both the individual and the employing organizations. The four benefits that were identified were: „1) widening access to higher education; 2) direct impact on the workplace of the investigation or project of the doctoral student; 3 ) effective personal and professional growth for the candidate; and 4) employer benefits through capitalization on the learner's development.“ (p. 265). As noted earlier, St. Clair, et al. (2017) found need for greater student preparation and support from doctoral degree programs when students had goals that fell outside the traditional pathway of academia.

\section{Methodology}

\section{Description of Research Design}

Over four school years, a qualitative study was conducted in which projects and activities were integrated into 30 sections of different graduate courses in counseling to promote better connnection of students to desired job components before completion of the degree. The majority of students were already working in the general field of study, such as school teachers who were pursuing a degree in school counseling. Online courses averaged 20 students per course and campus courses averaged 12 students per course. This was a result of faculty observation that many students obtained a graduate degree and either stayed in a job that did not require the degree or took several years to find a job match for the degree. While some students verbalized desire to stay in current geographic locale, even if not finding and advanced skills job, there was also indication that courses perhaps focused more heavily on academic mastery of content than with practical application for the job field. Examples were heavy reliance on writing papers and providing article critiques. The focus of this research was to ascertain benefits of inclusion of more course components that would expose students to actual work in the ,real world." This research focused on the four areas indicated above by research: Engagement in work-simulated skills practice; engagement in course group 
activiteis; participation in service learning volunteerism; and student proactivity.

\section{Engagement in work-simulated skills practice}

The focus of some courses provide strong support for integration of work-simulated skills practice. One example is theories and techniques courses in which students learn constructs of various counseling theories with accompanying techniqiues per each theory. In this course, students indicate a real-life concern that they would feel comfortable talking about in a role-play scenario with a fellow students. After instruction with theory techniques, students then role play using the technique as both the client role and the counselor role. Then at the end of the course, an assessment is given in which course students are given random assignments of a scenario, the role of client or counselor, and a technique to demonstrate. This was rotated among students until all students had opportunity to demonstrate counselor and client roles in the assessment.

While counseling skills are demostration of skills as interacted between people, some desired skills are more individualized such as creativity, organization, planning, and program development. An example in which this was integrated was an introduction to school counseling course, where students were required to develop a comprehensive school counseling program, such as they would be required to develop upon starting a job as a school counselor. This project required students to consult with practicing school counselors as well as research of professional guidance from professional standards, organizations, and published texts or journal articles. The course assignment then produced a product that students could take as a selling point when starting as a job search and inteviewing for potential jobs.

\section{Engagement in course group activities}

As much as work is done in groups within employment settings, group assignments in courses provided opportunity for students to grow in teamwork skills of communication and collaboration. Most courses lended themselves to integration of group work for some facet of course focus. In the online learning modality, discussion forums are a common group learning experiece in which students typically post a thread of discussion on the assigned topic for the forum and then students reply back and forth to each other regarding these thread. Similar assignments were given in campus classes with which students would divide into groups and discuss together a topic prompt from the instructor.

While students reported benefit and enjoyment of group discussion assignments, there was less enthusiasm for group work to develop a product together. These assignments typically revealed a diversity of student 
committment to work required and diversity of timiliness in completion of „their part" of the group task. Both campus and online students seemed to prefer that their larger assignments be per individual effort so that they could control the results better.

\section{Service-learning and volunteerism.}

Three areas of course content were enriched through integration of service-learning/volunteer projects as student assignments - Counseling Multicultural Populations, Counseling Theories and Techniques, and Lifespan Development and Learning. The service-learning work in these areas are shown in table 1 .

Table 1 Courses and Service-LearningVolunteer Projects

\begin{tabular}{|c|c|c|}
\hline Course & Project & Description of Project \\
\hline $\begin{array}{l}\text { Counseling } \\
\text { Multicultural } \\
\text { Populations }\end{array}$ & $\begin{array}{c}\text { Cultural Immersion } \\
\text { Project }\end{array}$ & $\begin{array}{l}\text { Students engaged in an experience } \\
\text { with a culture other than their own, } \\
\text { in which the student experienced } \\
\text { slices of life of that culture over } \\
\text { several weeks during the course, so } \\
\text { as to obtain in-depth knowledge of } \\
\text { life in that culture. }\end{array}$ \\
\hline $\begin{array}{c}\text { Counseling Theories \& } \\
\text { Techniques }\end{array}$ & $\begin{array}{l}\text { Theoretical Intervetion } \\
\text { with a volunteer } \\
\text { regarding health } \\
\text { promotion. }\end{array}$ & $\begin{array}{l}\text { Students worked with a volunteer } \\
\text { within the framework of a selected } \\
\text { theory to help assess current healthy } \\
\text { lifestyle habits, plan goals and } \\
\text { activities to strengthen those habits, } \\
\text { conduct some planned activities, } \\
\text { and evaluate how the activities } \\
\text { helped to achieve their goals. }\end{array}$ \\
\hline $\begin{array}{c}\text { Lifespan Development } \\
\& \text { Learning }\end{array}$ & $\begin{array}{l}\text { Development of a web- } \\
\text { site page on a current } \\
\text { issue need for a certain } \\
\text { life-span stage. }\end{array}$ & $\begin{array}{l}\text { Students interviewed persons in and } \\
\text { stakeholders of a given life-span } \\
\text { stage such as students, parents, and } \\
\text { teachers on priority needs of that } \\
\text { life-span stage. Students then } \\
\text { developed a website to address a } \\
\text { selected need area to include both } \\
\text { static and interactive content to serve } \\
\text { as a resource for stakeholders } \\
\text { regarding that need. Students then } \\
\text { asked their interviewees for } \\
\text { feedback on the efficacy. }\end{array}$ \\
\hline
\end{tabular}

\section{Student pro-activity}

While there are many resources such as websites and professional organizations that offer information to students about potential employment to align with the training in the respective degree program, there is still a need for individual student effort toward effective preparation and self-advocacy in the search for emplyment that is accurately aligned with the training of the 
degree program. Most institutions do offer career counseling for the student body and these have many helpful resources such as resume preparation and various interest inventories to help students increase more accurate awareness of their strengths and interests that could be carried into a job. Some courses provide content that could be framed as student pro-activity in preparation for the eventual career. A course on professional orientation was a strong modality in which to encourage students in professional pro-activity through assignments that integrated that. Several assignments were designed toward these. Students compiled a resource notebook that included resource information that students could use in a job on professional support such as profession organizations, personal self-care such as physical exercise resources, support resources for students and for families such as family emergency or social service resources, and support resources for ethics and legal guidance such as state department of education legal support or the local school district attorney's contact information.

One of the most beneficial student pro-activity assignments is to have students develop a professional plan from where they currently are to the point of qualification and job hire. In the course on professional orientation, students had an assignment to develop such as plan. This plan included idenfication of requirements to attain professional certification or licensure and plan of how student would meet that; plan for any required practicum or internship; plan for professional networking such as national, state, local, and special interest groups that could give a student guidance, mentoring, and even information and connections for possible jobs in the field; and identification of sources of continuing education that they could use to maintain and renew a professional license once received. The final part of the plan was for students to include a professional statement of practice which would clarify for students, clients, and colleagues the services that would be provided, assurance of confidentiality, expectations of the person receiving counseling, and contact source of governing code of ethics as well as office where the professional license was issued.

\section{Summary Results of Project}

Across the courses and sections in which employment skill and knowledge activities were integrated, student feedback in both assignment reflections and end of course feedback indicated perceived efficacy of these assignments for career preparation and enhancement of those job skill and aptitute areas. A few examples of student feed back were: was able to learn things about

- $\quad$ I was able to learn things about myself and was asked to think about what I was learning and how I could apply it to my professional and personal life. 
- $\quad$ All the information is vital to my career choice and gave insight and background to counseling techniques I was unfamiliar with.

- $\quad$ This experience reminded me that while I may only be working as a school counselor at one school, my daily impact on students and their families may result in years of support in the future.

- Initially, I thought my research would just provide me with more information on knowledge I already acquired. I was thrilled to not only strengthen my previous knowledge but to gain more.

- $\quad$ This alters my future by giving me an even more positive outlook on shaping my future children and being a strong system of support and motivation for my age group and others.

As noted by Hollingsworth and Rochester (2016), " Upon post degree employment, university graduates have found a dichotomy between what was learned and what was practiced in the real-world." (p. 86). Student feedback and professor observation indicated benefit and efficacy for student preparation in finding desirable employment match upon completion of their course of study. This benefit and efficacy extended to institutions as enhanced preparation for employment increased marketing success and to prospective employers as their pool for potential employees grew.

\section{Conclusion}

Previous research has indicated challenges for students, both undergraduate and graduate, to find employment that matches their academic preparation. Previous research as also indicated challenges for employers in finding sufficient qualified new hires for existing job vacancies. This study focused on minimizing the mismatch for both students and employers through integration of relevant job skills and aptitutes into course assignments. Results from student feedback and professor observation indicated that this integration does offer benefit and efficacy to students, institutions, and employers.

This study was conducted in one degree program at one university. Continuing examination of such integration into courses is still needed with multiple academic programs of study, multiple geographic locales, and multiple types of institutions of higher education. This further research should also integrate long-term assessment of efficacy, such as follow-up assessment by students and employers at selected periods of time after degree is completed and student has worked in the field, such as one-year out and five years out.

To return to the beginning of this discussion, students do too often see the null hypothesis proven, that „this degree did not get me this job.“ With integration of desirable employment activities as course activities, this can change. Students can begin to see their hypothis proven more that „This degree will get me this type of job.“ 


\section{References:}

1. Clayton, Patti H. (2009) Service-learning as democratic civic engagement: Building capacity for a lifetime of collaborative change agency. Indianapolis, IN, Center for Service and Learning at Indiana University.

2. Coates, H. \& Edwards, D. ( 2010). The Graduate Pathways Survey: New insights on education and employment outcome five years after bachelor degree completion. The Australian Higher Education Quarterly, 65(1), 74-93.

3. Costley, C. \& Lester, S. (2012). Work-based doctorates: Professional extension at the highest levels. Studies in Higher Education. 37(3), 257-269.

4. ECC is right to pursue consolidating nursing program near Medical Campus (2015, November). The Buffolo News.

5. Gorski, D. (2015, April). Degrees of certainty. Best's Review, 62-67.

6. Hamer, L.O. \& O'Keefe, R.D. (2013). Achieving change in student's attitudes toward group projects by teaching group skills. Journal of Higher Education Theory and Practice, 13(2), 25-33.

7. Hollingsworth, M.A. \& Rochester, P.R. (2016). Enhancement of student preparation for global service. International Journal of Humanities and Social Science Intervention, 5(9), 82 - 87.

8. Konyu-Fogel, G, DuBois, M.B. \& Wallingford, V. (2013). Learning communities and team-based learning: Developing management and business competencies. Journal of Management Policy and Practice, 14(5), 70-79.

9. Kumari, S. \& Nandal, S. (2016). Emergence of project-based learning in professional education. Scholedge International Journal of Multidisciplinary \& Allied Studies, 03(10), 208-214.

10. Lee, J.G. (2015). Training match and mismatch as a driver of key employeed behaviors. Human Resource Management Journal, 25(4), 478-495.

11. Lim, H., Rich, J. \& Harris, M.N. (2008). Employment outcomes of graduates: The case of Universti Utara, Malaysia. Asian Economic Journal, 22(3), 321-341.

12. Lou, Y. (2004). Learning to solve complex problems through between-group collaboration in project-based online courses. Distance Education, 25(1), 49-66.

13. Nunley, J. M, Pugh, A., Romereo, N, \& Seals, R. A. (2017). The effects of unemployment and underemployment on employment opportunities: Results from a correspondence audit of the labor market for college graduates. ILR Review, 70(3), 642-669. 
14. Roksa, J. \& Levey, T. (2010). What can you do with that degree? College major and occupational status of college graduates over time. Social Forces, 89(2), 389-416.

15. Siew, M.M. \& Mapeala, R. (2017). The effects of thinking maps-aided problem-based learning on motivation towrds science learning among fifth graders. Journal of Baltic Science Education, 16 (3), 379-384.

16. St. Clair, R. Hutto, T., Macbth, C., Newstetter, T., McCarty, N.A., \& Melkers, J. (2017). The „new normal:“ Adapting doctoral training career preparation for broad career paths in science. PloS One, 12(5), $1-19$.

17. Van der Putten, M , \& Vichit-Vadakan, N. (2010). A pilot use of team-based learning in graduate public health education. Southeast Asian Journal of Tropical Medicine and Public Health, 41(3), 743753.

18. Wertel, M. (2015 September/October). What can I do with this degree? Change, 28 - 34 